\title{
Tamoxifen Modulates Cell Migration and Expression of Angiogenesis-Related Genes in Human Endometrial Endothelial Cells
}

\author{
Malin Helmestam, ${ }^{*}$ Helén Andersson, ${ }^{\dagger}$ \\ Anneli Stavreus-Evers, ${ }^{*}$ Eva Brittebo, ${ }^{\dagger}$ and \\ Matts Olovsson* \\ From the Departments of Women's and Children's Health* and \\ Pharmaceutical Biosciences, ${ }^{\dagger}$ Uppsala University, Sweden
}

The selective estrogen receptor modulator tamoxifen is used for the prevention and treatment of breast cancer. The adverse effects of tamoxifen include vaginal endometrial bleeding, endometrial hyperplasia, and cancer, conditions associated with angiogenesis. The aim of this study was to examine the effects of tamoxifen on cell migration and angiogenesis-related gene expression in human endometrial endothelial cells (HEECs). The regulatory effects of tamoxifen on endometrial stromal cells and HEECs were also examined. HEECs and stromal cells were isolated and grown in monocultures or co-cultures, and incubated with 0.1 to $100 \mu \mathrm{mol} / \mathrm{L}$ tamoxifen for 48 hours. Quantitative PCR demonstrated that tamoxifen decreased the mRNA expression of vascular endothelial growth factor-A (VEGF-A) and increased the mRNA expression of VEGF receptor-1 and placental growth factor (PLGF) in HEECs. Tamoxifen's effects on VEGF-A were inhibited when HEECs were co-cultured with stromal cells. In addition, tamoxifen reduced VEGF-induced HEEC migration. The tamoxifen-metabolizing enzymes CYP1A1 and CYP1B1 were detected by immunohistochemistry in and around endometrial blood vessels and by quantitative PCR in HEECs. Our data suggest that tamoxifen changes the regulation of angiogenesis in the endometrium, likely by reducing angiogenic activity. The results also indicate that endometrial stromal cells regulate some of tamoxifen's effects in HEECs, and the presence of tamoxifen-metabolizing enzymes suggests tamoxifen bioactivation in the endometrial vasculature in vivo. These findings may help to elucidate the mechanism of the bleeding disturbances associated with tamoxifen treatment. (AmJ Pathol 2012, 180:2527-2535; http://dx.doi. org/10.1016/j.ajpath.2012.02.026)
The selective estrogen receptor modulator tamoxifen is the most widely used agent for prevention and treatment of estrogen receptor (ER)-positive breast cancer. ${ }^{1,2}$ Tamoxifen treatment inhibits breast cancer growth and prevents breast cancer relapse, but it is also associated with benign lesions and malignant tumors in the human endometrium. ${ }^{3}$ The adverse effects of tamoxifen on the endometrium include endometrial hyperplasia and cancer, conditions that are strongly associated with angiogenesis. ${ }^{4}$

Previous studies of tamoxifen's effects on human endometrial cells have focused on epithelial and stromal cells, and less is known about the effects on human endometrial endothelial cells (HEECs). ${ }^{5,6}$ Endothelial cells constitute the inner lining of blood vessels and play a key role in angiogenesis. HEECs express estrogen receptor $(E R) \beta_{,}^{7,8}$ a feature that makes them potential targets of tamoxifen. During angiogenesis, HEECs interact with stromal cells surrounding the blood vessels. ${ }^{9}$ Since endometrial stromal cells express $\mathrm{ER} \alpha$ and $\mathrm{ER} \beta,^{10,11}$ they are also potential targets of tamoxifen. Tamoxifen might thus affect angiogenesis in the endometrium either through direct effects on HEECs or through indirect effects via surrounding stromal cells, or both.

Endothelial cell proliferation is promoted by ER signaling. ${ }^{12,13}$ Once activated, the ER undergoes a conformational change and regulates transcription of estrogen responsive genes by binding to the estrogen-responsive elements. ${ }^{14}$ The two classical estrogen receptors, ER $\alpha$ and $\mathrm{ER} \beta$, share a common structure; however, differences in their $\mathrm{NH}_{2}$-terminal regions make them respond differently to various ligands, especially to selective es-

Supported in part by the European Commission in Framework Program 6 as Integrated Project (IP) LSHB-CT-2004-503257 (project title: Development of a novel approach in hazard and risk assessment of reproductive toxicity by a combination and application of in vitro, tissue and sensor technologies), FORMAS (Dnr 216-2005-894), the Swedish Scientific Council (2005-7293), the Swedish Fund for Research without Animal Experiments, and the Family Planning Fund in Uppsala.

Accepted for publication February 23, 2012

Address reprint requests to Matts Olovsson, M.D., Ph.D., Department of Women's and Children's Health, Uppsala University, entrance 96, nbv, Uppsala SE-751 85, Sweden. E-mail: Matts.Olovsson@kbh.uu.se. 
trogen receptor modulators. ${ }^{15,16}$ Both estrogen receptors are widely distributed throughout the body, showing distinct cell- and tissue-specific expression, but also overlapping co-expression in a variety of tissues. ${ }^{17}$ Depending on tissue and cell type, tamoxifen can function both as an ER antagonist or as an agonist. ${ }^{15,18}$ The antagonistic mode of action of tamoxifen is seen in breast tissue, where it inhibits breast cancer cell proliferation. In contrast, tamoxifen has been reported to function as an ER agonist in the endometrium, where it promotes epithelial cell proliferation. ${ }^{19}$

Cytochrome P450 (CYP) enzymes metabolize tamoxifen to an array of metabolites, with mixed agonistic and antagonistic effects on estrogen receptors, of which 4-hydroxytamoxifen and endoxifen are reported to be the most pharmacologically active metabolites. ${ }^{19,20}$ CYP3A and CYP2D6 have been identified as the major hepatic enzymes involved in the principal routes of tamoxifen metabolism; however, CYP1A1, CYP1A2, CYP1B1, CYP2B6, CYP2C8, CYP2C9, and CYP2C 19 can also contribute to bioactivation. ${ }^{20-22}$ The expression of various CYP forms in the endometrium may affect the local formation of biologically active tamoxifen metabolites and may also contribute to the tissue-specific response to tamoxifen. ${ }^{23,24}$

Little is known about the effects of tamoxifen on human endometrial vasculature. Some reports suggest that tamoxifen modulates the expression of angiogenic factors in human endometrial vasculature both in vivo and in vitro, and that the antitumor effect of tamoxifen in breast tissue may be related to its antiangiogenic action. ${ }^{25-27}$ The aim of this study was to examine the effects of tamoxifen on angiogenesis-related genes and cell migration in HEECs and to examine whether tamoxifen's effects in HEECs are altered in the presence of stromal cells. Furthermore, the expression of tamoxifen-metabolizing CYP enzymes in the human endometrial vasculature was investigated to determine whether local metabolism of tamoxifen may occur in this tissue.

\section{Materials and Methods}

The Ethics Committee at Uppsala University, Sweden, approved the study. Informed consent was obtained from all women included in the study.

\section{Materials}

Tamoxifen and $17 \beta$-estradiol were purchased from Sigma-Aldrich (St. Louis, MO), and stock solutions in ethanol were prepared. Cell Proliferation ELISA, BrdU kit and cell viability WST-1 reagents were purchased from Roche Diagnostics Scandinavia AB (Bromma, Sweden). Collagen and vascular endothelial growth factor-A (VEGF-A), used in migration assays, were obtained from Invitrogen (Carlsbad, CA). Endothelial cell culture media (ECM) and fetal calf serum (FCS) were purchased from ScienCell Research Laboratories (Calsbad, CA). The FCS estradiol concentration was $35 \mathrm{pmol} / \mathrm{L}$ according to an estradiol radioimmunoassay from Siemens Diagnostics (Deerfield, IL).
For CYP mRNA expression analyses, TaqMan Kit reagents (Applied Biosystems, Foster City, CA) and qPCR MasterMix Plus for SYBR Green I (Eurogentec, Seraing, Belgium) were used. Primers were designed by using the Universal Probe Library primer design tool (Roche Diagnostics, Basel, Switzerland) and purchased from DNAtechnology (Aarhus, Denmark). Primary antibodies, rabbit anti-human CYP1A1, CYP1B1, CYP2A6, CYP2B6, CYP2C8/2C9/2C 19, CYP2D6, and CYP3A4/5 were purchased from Millipore, Chemicon (Billerica, MA). According to the manufacturer, these antibodies do not crossreact with other CYP enzymes. The secondary antibodies used were a biotin-labeled swine anti-rabbit IgG from DAKO Cytomation (Glostrup, Denmark) or biotin-labeled horse anti-rabbit/mouse/goat IgGs from Vector Laboratories (Burlingame, CA). Avidin-biotin peroxidase complex $(A B C)$ and Vector VIP substrate kits for peroxidase assay were obtained from Vector Laboratories (Burlingame, CA). Bovine serum albumin (BSA) was purchased from Sigma-Aldrich (St. Louis, MO). Hydrogen peroxide was purchased from VWR International (Stockholm, Sweden).

\section{Cell Cultures}

Endometrial biopsy samples from four women at fertile age undergoing hysterectomy for benign medical conditions at Uppsala University Hospital were obtained, and cultures of endothelial and stromal cells were established, maintained, and characterized as previously described. ${ }^{28,29}$ Several of our previous studies have demonstrated that there are no differences between HEECs from the proliferative and secretory menstrual phases concerning HEEC viability and proliferation as well as gene expression when exposed to VEGF-A, several different hormones and endocrine disrupting chemicals $^{29,30-32}$ and therefore no comparison was made between cells from the two menstrual phases.

Each biopsy sample gave rise to one monoculture and one co-culture, and cells from different women were not pooled. HEECs and stromal cells from these four biopsies were used in all of the cell proliferation and cell viability assays as well as for immunohistochemistry and the quantitative PCR (qPCR) experiments. HEECs in passage 2 were grown as monocultures or as co-cultures with stromal cells in ECM and exposed to tamoxifen, $17 \beta$-estradiol, or vehicle. Co-cultured HEECs were grown together with stromal cells in inserts, allowing communication but no direct contact between the two cell types. Both endothelial and stromal cells were exposed to the test substances during the experiments.

\section{Exposure to Test Substances}

HEECs were exposed to tamoxifen, $17 \beta$-estradiol, or vehicle for 48 hours. Before the experiment, the tamoxifen stock solution was diluted in cell culture medium to final concentrations of $0.01,0.1,1,10$, and $100 \mu \mathrm{mol} / \mathrm{L}$. $17 \beta$ Estradiol stock solution was also diluted in cell culture medium, to a final concentration of $0.01 \mu \mathrm{mol} / \mathrm{L}$. The ethanol concentration of all final solutions was $0.1 \%(\mathrm{v} / \mathrm{v})$. 
Cell culture medium with $0.1 \%(\mathrm{v} / \mathrm{v})$ ethanol was used as vehicle control.

\section{Proliferation and Viability Assays}

Proliferation and viability assays were performed in six replicates from each individual according to the kit and reagent manufacturer's instructions. HEECs were exposed to cell culture medium containing 0.01 , 1, or 100 $\mu \mathrm{mol} / \mathrm{L}$ tamoxifen or vehicle for 48 hours. Briefly, in proliferation assays, tamoxifen-treated HEECs were exposed to BrdU labeling solution for the last 24 hours of the 48-hour incubation. Labeling was visualized using a peroxidase reagent, and absorbance was measured at 450 $\mathrm{nm}$. Viability was assessed using a WST-1 kit, in which 10 $\mu \mathrm{l}$ of WST-1 solution was added to the tamoxifen-treated HEECs for the last hour of the 48-hour incubation. After a 1-hour incubation at $37^{\circ} \mathrm{C}$, the absorbance was measured at $450 \mathrm{~nm}$.

\section{Migration Assays}

Cell migration was determined by using a modified Boyden chamber (Neuro Probe, Gaithersburg, MD). HEECs in monocultures or HEECs co-cultured with stromal cells were incubated for 48 hours in culture medium containing $0.01,0.1,1$, or $10 \mu \mathrm{mol} / \mathrm{L}$ tamoxifen or vehicle. The lower chamber in the Boyden chamber was filled with one of the following: ECM; or ECM with $10 \%$ extra FCS; or ECM with $100 \mathrm{ng} / \mathrm{mL}$ VEGF-A 165. An 8- $\mu \mathrm{m}$ pore polycarbonate filter was coated with collagen solution $(100 \mu \mathrm{g} / \mathrm{mL})$ and placed between the two compartments of the chamber. After 48 hours' exposure to tamoxifen, mono- and co-cultured HEECs were transferred to the upper compartment of the Boyden chamber at a density of $3.5 \times 10^{4}$ cells per well, together with the tamoxifen-containing medium. The cells were then allowed to migrate for 5 hours at $37^{\circ} \mathrm{C}$. The filter was then removed, and the upper side of the filter containing the nonmigrated cells was wiped and rinsed. The filter was fixed in pure methanol and treated with Giemsa stain, after which the number of cells that had migrated to the lower chamber was viewed at $\times 20$ magnification and counted. Each condition was assayed in triplicate.

\section{RNA Isolation, cDNA Synthesis, and qPCR}

RNA was isolated from monocultured and co-cultured HEECs for analysis of mRNA expression as previously described. ${ }^{28}$ Analyses of angiogenesis-associated factors, measurement of RNA purity, synthesis of CDNA, and qPCR were performed as previously described. ${ }^{28}$

For analysis of CYP mRNA expression, cDNA synthesis from $0.1 \mu \mathrm{g}$ of total RNA was performed with TaqMan Kit reagents, according to the manufacturer's protocol. QPCR was performed with QPCR MasterMix Plus for SYBR Green I with $20 \mu \mathrm{mol} / \mathrm{L}$ primer. A melt curve was included to ensure specific amplification. Primer sequences were as follows: CYP1A1: NC_000015.9, forward, 5'-CAGAAGATGGTCAAGGAGCA-3', reverse, 5'-GACATTGGCGTTCTCATCC-3', CYP1B1: NC_000002.11, forward, 5'-CGGCCACTATC-
ACTGACATC-3', reverse, 5'-CTCGAGTCTGCACATCAGGA-3'. HPRT1 and RPL13A were used as endogenous reference genes; the primer sequences have been presented previously. ${ }^{28}$

\section{Immunohistochemical Analysis of Tamoxifen- Metabolizing Enzymes in Human Endometrial Vasculature}

Protein expression of the major tamoxifen-metabolizing CYPs (CYP1A1, CYP1B1, CYP2A6, CYP2B6, CYP2C8/9/ 19, CYP2D6, and CYP3A4/5) in the vasculature of formalin-fixed human endometrial biopsy samples from 11 women was investigated by immunohistochemical analysis according to protocols previously described. ${ }^{23}$

\section{Statistical Analysis}

When comparing the data on proliferation and viability of HEECs exposed to tamoxifen and vehicle, the means of the six replicates from each individual were used in the statistical analysis, which was performed by using the Mann-Whitney $U$-test. Mean normalized expression based on the ratio between mean Ct-values of target and reference genes and the efficiency of the PCR reactions, was calculated as a measure of target gene transcription, as described by Muller et al. ${ }^{33}$ Data are presented as $\log _{2}$-fold change to illustrate the difference between HEECs exposed to tamoxifen or vehicle.
Viability
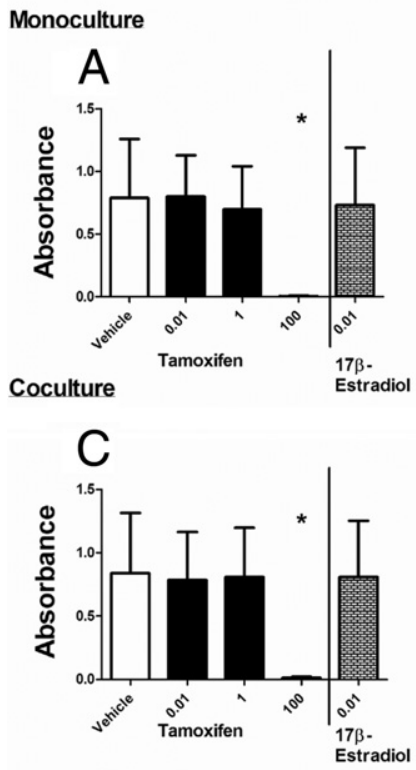

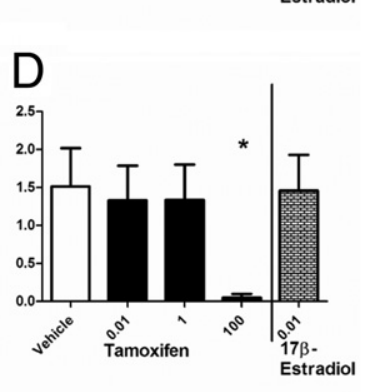

Proliferation

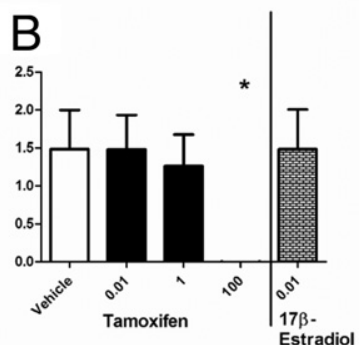

tradiol

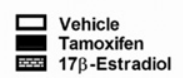

Figure 1. Effects of exposure to tamoxifen $(0.01,0.1,1$, and $10 \mu \mathrm{mol} / \mathrm{L})$ and $17 \beta$-estradiol $(0.01 \mu \mathrm{mol} / \mathrm{L})$ on HEEC proliferation and viability, in monoculture ( $\mathbf{A}$ and $\mathbf{B}$ ), and in co-culture with endometrial stromal cells ( $\mathbf{C}$ and $\mathbf{D}$ ). Absorbance is presented as $\mathrm{A}_{450} \mathrm{~nm}-\mathrm{A}_{690} \mathrm{~nm}$. Significantly different from control at ${ }^{*} P<0.05$. Data are mean \pm SEM. 


\section{Monoculture}
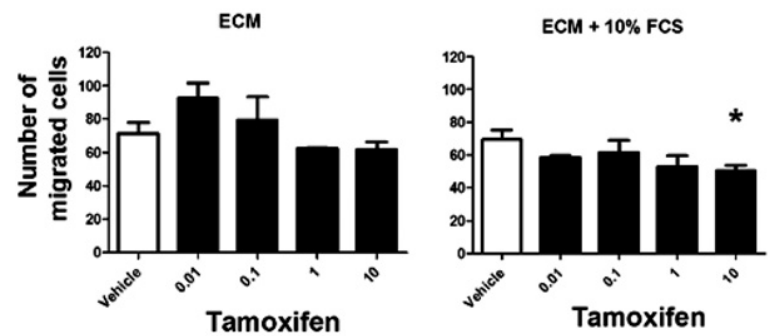

Coculture

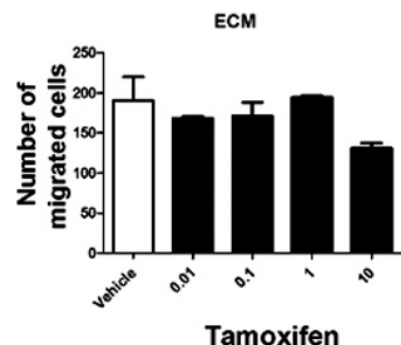

Tamoxifen

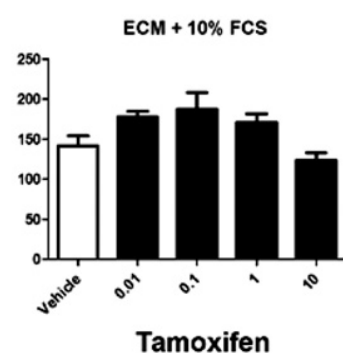

Tamoxifen

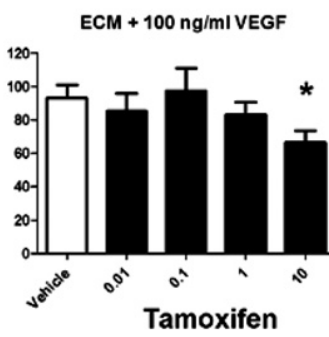

Figure 2. Migration of HEECs after tamoxifen exposure. HEECs were grown in monoculture and in co-culture with stromal cells and exposed to tamoxifen $(0.01,0.1,1$, and $10 \mu \mathrm{mol} / \mathrm{L})$ for 48 hours Thereafter HEEC migration was analyzed after 5-hours exposure to endothelial cell culture medium (ECM), ECM supplemented with FCS (10\%), or ECM supplemented with $100 \mathrm{ng} / \mathrm{mL}$ of VEGF. Significantly different from control (vehicle) at ${ }^{*} P<0.05$. Data are mean \pm SEM.
The Mann-Whitney U-test was applied to compare qPCR and migration data. Values of $P \leq 0.05$ were considered to denote a statistically significant difference. To reduce intersubject variance caused by differences in baseline between subjects, data from all subjects were normalized in relation to their controls. Two-way analysis of variance was used to compare the effects of tamoxifen on HEECs in monoculture versus cells co-cultured with endometrial stromal cells. The two-way analysis of variance demonstrated the influence of stromal cells on HEEC proliferation, viability, and mRNA expression. Tukey's honestly significant difference (HSD) test was used as a post hoc test. $P$ values of $\leq 0.05$ were considered to denote a statistically significant difference. All statistical analyses were performed using the Statistical Package for the Social Sciences (SPSS), version 15 (SPSS Inc., Cary, NC).

\section{Results}

\section{Effects of Tamoxifen on HEEC Proliferation and Viability}

There were no changes in proliferation or viability in mono- or co-cultured HEECs exposed to 0.01 or $1 \mu \mathrm{mol} / \mathrm{L}$ tamoxifen compared with vehicle for 48 hours, whereas both proliferation and viability decreased after exposure to $100 \mu \mathrm{mol} / \mathrm{L}$ tamoxifen (Figure 1).

\section{Effects of Tamoxifen Migration of HEECs in Response to VEGF-A and FCS}

The migration assay demonstrated that 48 hours' exposure to $10 \mu \mathrm{mol} / \mathrm{L}$ tamoxifen reduced VEGF-stimulated migration of HEECs in both mono- and co-culture and reduced FCSstimulated migration of HEECs in co-culture. According to the analysis of variance, the presence of stromal cells did not have any effect on HEEC migration during tamoxifen exposure. HEEC migration was not affected by exposure to $0.01,0.1$, or $1 \mu \mathrm{mol} / \mathrm{L}$ tamoxifen (Figure 2).

\section{Effects of Tamoxifen on mRNA Expression of Angiogenesis-Related Genes in HEECS}

Tamoxifen down-regulated the VEGF-A mRNA expression in monocultures of HEECs when exposed to $0.01 \mu \mathrm{mol} / \mathrm{L}$ $\left(-1.87 \log _{2}\right.$-fold change, $\left.P=0.037\right)$ and $1 \mu \mathrm{mol} / \mathrm{L}(-1.59$ $\log _{2}$-fold change, $P=0.037$ ). In contrast, a slight upregulation was detected in co-cultures of HEECs exposed to 10 $\mu \mathrm{mol} / \mathrm{L}$ tamoxifen $\left(0.07 \mathrm{log}_{2}\right.$ foldchange, $\left.P=0.014\right)$. A comparison between HEECs in monocultures and HEECs in co-cultures demonstrated that the presence of stromal cells abolished the tamoxifen-induced down-regulation $\left(F_{1,22}=\right.$ 7.85; $P<0.01$ ) (Figure 3A).

Tamoxifen upregulated placental growth factor (PLGF) mRNA expression in HEECs grown in monoculture and in co-culture with stromal cells. The expression of PLGF mRNA was upregulated in monocultures of HEECs exposed to $0.01 \mu \mathrm{mol} / \mathrm{L}\left(0.95 \log _{2}\right.$-fold change, $\left.P=0.037\right)$, $0.1 \mu \mathrm{mol} / \mathrm{L}\left(1.06 \log _{2}\right.$-fold change, $\left.P=0.037\right)$, and 1 $\mu \mathrm{mol} / \mathrm{L}$ tamoxifen (1.29 $\log _{2}$-fold change, $P=0.037$ ). Also, the PLGF mRNA expression in HEECs co-cultured with stromal cells was increased after exposure to 0.01 $\mu \mathrm{mol} / \mathrm{L}\left(1.3 \log _{2}\right.$-fold change, $\left.P=0.019\right), 0.1 \mu \mathrm{mol} / \mathrm{L}$ (0.99 $\log _{2}$-fold change, $\left.P=0.014\right), 1 \mu \mathrm{mol} / \mathrm{L}\left(1.43 \log _{2^{-}}\right.$ fold change, $P=0.019$ ), and $10 \mu \mathrm{mol} / \mathrm{L}$ tamoxifen (1.43 $\log _{2}$-fold change, $\left.P=0.014\right)$. Thus, the presence of stromal cells did not change tamoxifen's effects on PLGF mRNA expression in HEECs (Figure 3B).

Tamoxifen upregulated VEGF receptor-1 (VEGFR-1) mRNA expression in HEECs co-cultured with stromal cells exposed to $0.01 \mu \mathrm{mol} / \mathrm{L}\left(0.97 \log _{2}\right.$-fold change, $P=$ $0.019), 1 \mu \mathrm{mol} / \mathrm{L}\left(0.49 \log _{2}\right.$-fold change, $\left.P=0.019\right)$, and $10 \mu \mathrm{mol} / \mathrm{L}$ tamoxifen (1.52 $\log _{2}$-fold change, $P=0.014$ ), 

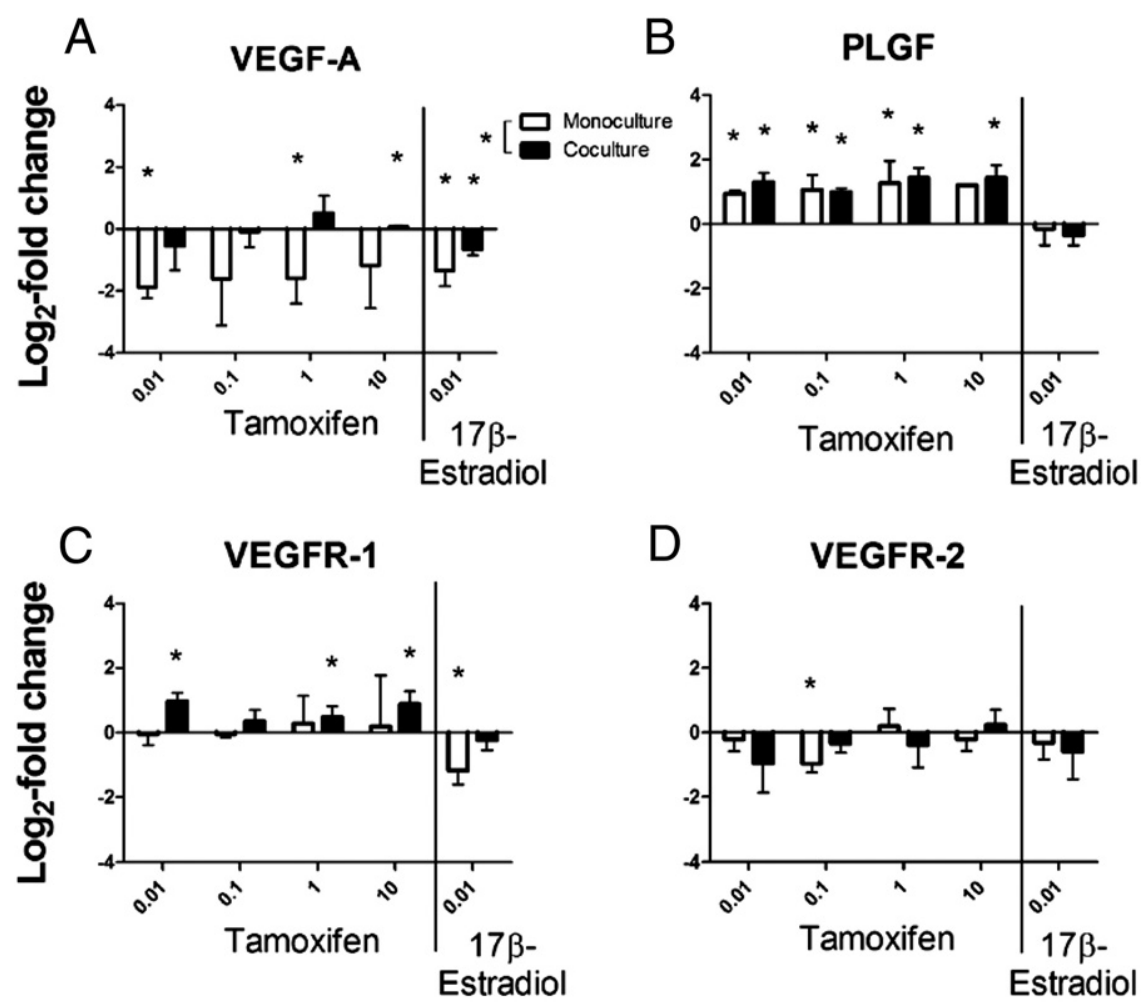

D VEGFR-2

E

HIF-1a

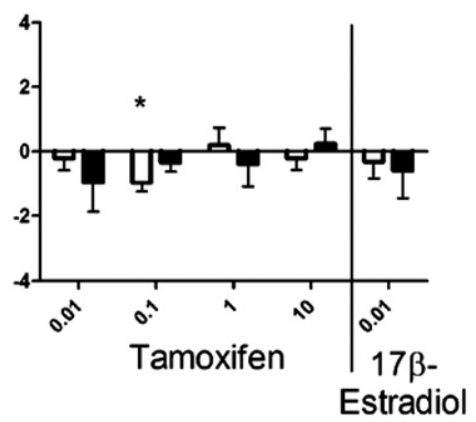

Figure 3. $\log _{2}$-fold changes in the expression of angiogenesis-related genes in HEECs exposed to tamoxifen $(0.01,0.1,1$, and $10 \mu \mathrm{mol} / \mathrm{L})$, and $17 \beta$ estradiol $(0.01 \mu \mathrm{mol} / \mathrm{L})$. Relative mRNA expression of VEGF-A (A), PLGF (B), VEGFR-1 (C), VEGFR-2 (D), HIF-1 $\alpha(\mathbf{E})$ and ER $\beta(\mathbf{F})$. Data are mean \pm SEM. Significantly different from control at ${ }^{*} P<0.05$.

$\mathrm{F}$

ER- $\beta$

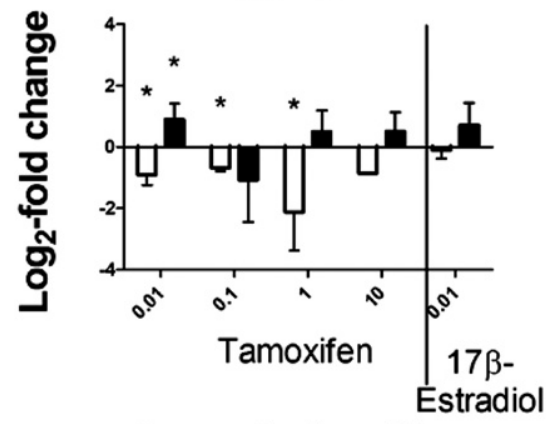

Concentration $\mu \mathrm{M}$

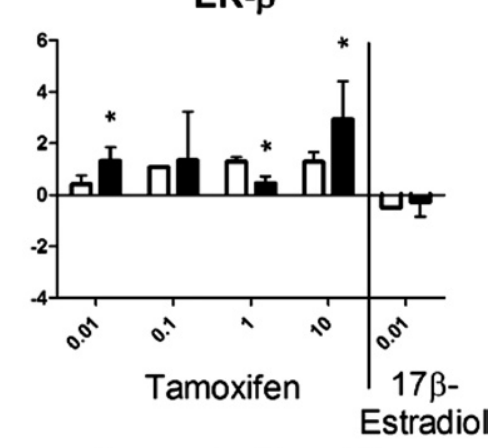

\section{Concentration $\mu \mathrm{M}$}

$\square$ Monoculture

Coculture

whereas the expression of VEGFR-1 remained unchanged in monocultures of HEECs (Figure 3C). The presence of stromal cells did not change tamoxifen's effects on VEGFR-1 mRNA expression in HEECs.

Tamoxifen down-regulated VEGF receptor 2 (VEGFR-2) mRNA expression in monocultures of HEECs after exposure to $0.1 \mu \mathrm{mol} / \mathrm{L}$ tamoxifen $\left(-0.39 \log _{2}\right.$-fold change, $P=$ 0.034) whereas the expression of VEGFR-2 remained unchanged in co-cultures of HEECs (Figure 3D). There were no significant differences in VEGFR-2 mRNA expression between monocultured and co-cultured HEECs after exposure to tamoxifen.

Tamoxifen down-regulated the hypoxia inducible factor-1 $\alpha(\mathrm{HIF}-1 \alpha)$ mRNA expression in monocultures of HEECs exposed to $0.01 \mu \mathrm{mol} / \mathrm{L}\left(-0.9 \log _{2}\right.$-fold change, $P=0.037), 0.1 \mu \mathrm{mol} / \mathrm{L}\left(-0.67 \log _{2}\right.$-fold change, $P=$ $0.037)$ and $1 \mu \mathrm{mol} / \mathrm{L}$ tamoxifen $\left(-2.12 \log _{2}\right.$-fold change,
$P=0.037)$. Also, the HIF-1 $\alpha$ mRNA expression in HEECs co-cultured with stromal cells was increased after exposure to $0.01 \mu \mathrm{mol} / \mathrm{L}$ tamoxifen (0.89 $\log _{2}$-fold change, $P=0.028$ ) (Figure 3E). There were no significant differences in HIF-1 $\alpha$ mRNA expression between monocultured and co-cultured HEECs after exposure to tamoxifen. Tamoxifen did not change von Willebrand factor (VWF) mRNA expression in HEECs exposed to tamoxifen (data not shown).

Effects of Tamoxifen on Expression of ER $\alpha$ and ER $\beta$ mRNA Expression in HEECs

The study results showed an upregulation of $\mathrm{ER} \beta$ mRNA expression in HEECs co-cultured with stromal cells after exposure to $0.01 \mu \mathrm{mol} / \mathrm{L}$ (1.33 $\log _{2}$-fold 

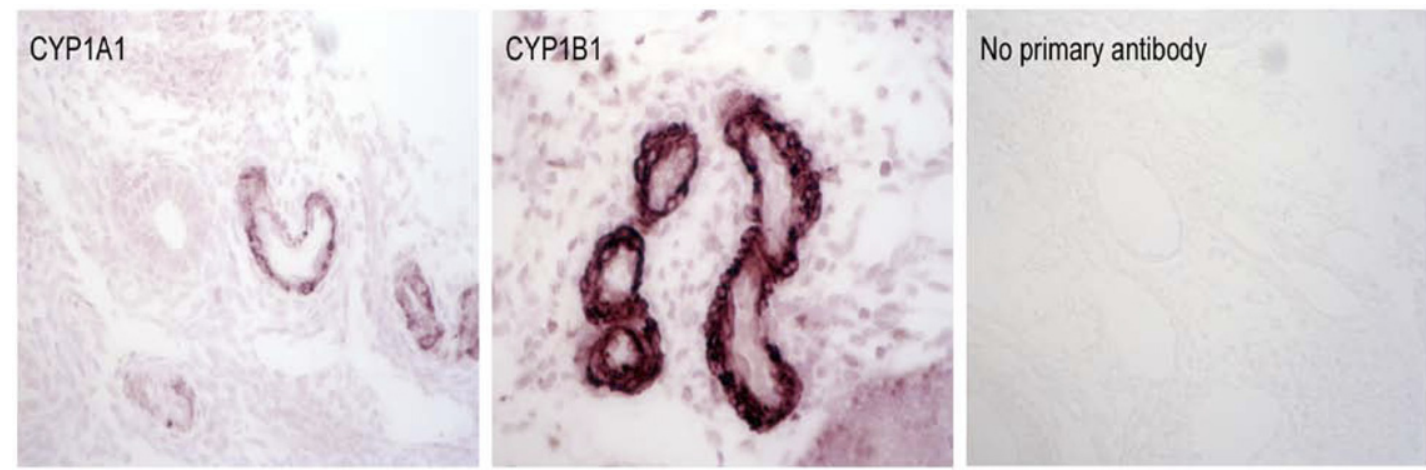

Figure 4. Immunohistochemical localization of tamoxifen-metabolizing enzymes in human endometrial vasculature. CYP1A1 and CYP1B1 are preferentially expressed in and around blood vessels. CYP1A1 displays weak to moderate expression in the stroma surrounding blood vessels and in the vessel walls. CYP1B1 displays a more distinct, moderate to strong expression in blood vessel walls. The figure shows representative images of samples considered as positive. Control (no primary antibody) is also shown.

change, $P=0.028), 1 \mu \mathrm{mol} / \mathrm{L}\left(0.83 \log _{2}\right.$-fold change, $P=0.028)$, and $10 \mu \mathrm{mol} / \mathrm{L}$ tamoxifen $\left(2.93 \log _{2}\right.$-fold change, $P=0.019$ ) (Figure $3 F$ ). There was also a tendency to an upregulation of ER $\beta$ mRNA in monocultures of HEECs when exposed to 0.01, 0.1, 1, and 10 $\mu \mathrm{mol} / \mathrm{L}$ tamoxifen $(P=0.053)$. Tamoxifen did not change the HEEC ER $\alpha$ mRNA expression (data not shown). There were no differences in $\operatorname{ER} \alpha$ or $\operatorname{ER} \beta$ mRNA expression between monocultured and cocultured HEECs after exposure to tamoxifen.

\section{Effects of $17 \beta$-Estradiol on mRNA Expression of Angiogenesis-Related Genes in HEECs}

$17 \beta$-Estradiol was included as a reference to compare the effects of tamoxifen on HEECs with those of a pure ER agonist. $17 \beta$-Estradiol significantly down-regulated VEGF-A mRNA expression in HEEC monocultures $\left(-1.32 \log _{2}\right.$-fold change, $P=0.037$ ) and in HEECs co-cultured with stromal cells $\left(-0.66 \log _{2}\right.$-fold change, $\left.P=0.019\right)$ (Figure $3 A$ ). VEGFR-1 mRNA was down-regulated in monocultures of HEECs when exposed to $17 \beta$-estradiol $\left(-1.18 \log _{2}\right.$-fold change, $P=0.037$ ) (Figure $3 C$ ).

\section{Expression of Tamoxifen-Metabolizing CYPs in Human Endometrial Vasculature}

There was a selective protein expression of CYP1A1 and CYP1B1 in the endometrial vasculature, although there was great interindividual variation in expression levels (Figure 4 and Table 1). Overall, the results demonstrated that CYP1A1 expression was more abundant in stroma surrounding the endometrial blood vessels and that the blood vessel walls displayed more intense staining of CYP1B1. None of the examined endometrial biopsy samples displayed vascular expression of CYP2A6, CYP2B6, CYP2C8/ 2C9/2C19, CYP2D6, or CYP3A4/5. Most of the tissue sections showed a weak staining in the stroma compared with the negative controls, indicating that weak CYP expression at this site cannot be excluded. No staining was observed in the negative controls without primary antibodies.

\section{CYP1A1 and CYP1B1 mRNA Expression in HEECs and Stromal Cells}

The levels of CYP1A1 and CYP1B1 mRNA were further investigated in monocultured HEECs and in HEECs and stromal cells in co-cultures. Quantifiable levels of

Table 1. Vascular Expression of CYP1A1 and CYP1B1

\begin{tabular}{|c|c|c|c|c|c|}
\hline \multirow[b]{2}{*}{ Individual } & \multirow{2}{*}{$\begin{array}{l}\text { Menstrual } \\
\text { phase }\end{array}$} & \multicolumn{2}{|r|}{ CYP1A1 } & \multicolumn{2}{|r|}{ CYP1B1 } \\
\hline & & Blood vessel wall & Stroma nearby blood vessel & Blood vessel wall & Stroma nearby blood vessel \\
\hline 1 & Proliferative & + & + & ++ & ++ \\
\hline 2 & Proliferative & - & - & ++ & - \\
\hline 3 & Proliferative & - & - & +++ & \\
\hline 4 & Proliferative & + & - & - & - \\
\hline 5 & Proliferative & - & - & +++ & - \\
\hline 6 & Secretory & ++ & - & + & - \\
\hline 7 & Secretory & - & - & ++ & - \\
\hline 8 & Secretory & + & ++ & - & - \\
\hline 9 & Secretory & - & + & +++ & - \\
\hline 10 & Secretory & ++ & ++ & - & - \\
\hline 11 & Secretory & - & ++ & ++ & - \\
\hline
\end{tabular}

Immunohistochemical staining intensity in endometrial samples from 11 healthy, fertile women was quantified as follows: -, no staining; + , weak staining; ++ , moderate staining; +++ , intense staining. 


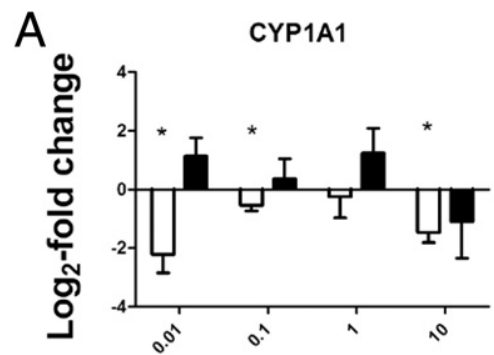

B

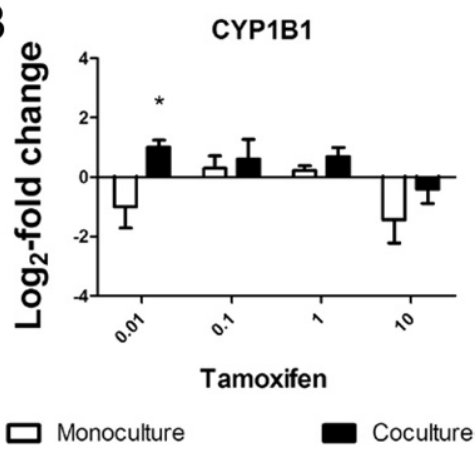

Figure 5. Log $_{2}$-fold changes of CYP1A1 (A) and CYP1B1 (B) mRNA levels in HEECs exposed to tamoxifen $(0.01,0.1,1$, and $10 \mu \mathrm{mol} / \mathrm{L})$ in monoculture and in co-culture with stromal cells. Data are mean \pm SEM. Significantly different from control as at ${ }^{*} P<0.05$.

CYP1A1 and CYP1B1 mRNA were detected in HEECs and stromal cells from the four individuals included in the study. The expression levels showed great variability between different cell types and individuals. CYP1A1 was preferentially expressed in stromal cells whereas CYP1B1 was mostly expressed in endothelial cells. Comparison of CYP1A1 and CYP1B1 expression in HEECs in co-cultures versus monocultures did not indicate that the presence of stromal cells had any impact on the expression of CYP1A1 or CYP1B1 in HEECs.

\section{Effects of Tamoxifen on Expression of CYP1A1 and CYP1B1 mRNA in HEECs}

The CYP1A1 mRNA expression in monocultured HEECs was down-regulated after 48 hours' exposure to 0.01 $\mu \mathrm{mol} / \mathrm{L}\left(-2.2 \log _{2}\right.$-fold change, $\left.P<0.014\right), 0.1 \mu \mathrm{mol} / \mathrm{L}$ (-0.54 $\log _{2}$-fold change, $\left.P<0.014\right)$, and $10 \mu \mathrm{mol} / \mathrm{L}$ tamoxifen $\left(-1.5 \log _{2}\right.$-fold change, $\left.P<0.019\right)$ compared with vehicle (Figure 5A). The CYP1B1 mRNA expression in HEECs co-cultured with stromal cells was upregulated after exposure to $0.01 \mu \mathrm{mol} / \mathrm{L}$ tamoxifen (Figure 5B). There were no significant differences in CYP1A1 or CYP1B1 mRNA expression between monocultured and co-cultured HEECs after exposure to tamoxifen.

\section{Discussion}

The results demonstrated that exposure to the selective estrogen receptor modulator tamoxifen increase the mRNA expression of the angiogenic factors VEGFR-1 and PLGF and decrease the mRNA expression VEGF-A in HEECs grown in vitro, suggesting that tamoxifen may change the regulation of angiogenesis and thus the endometrial vasculature. A comparison between HEECs response to tamoxifen and $17 \beta$-estradiol indicate that tamoxifen has an estrogenic effect on VEGF-A expression and an anti-estrogenic effect on VEGFR-1 and PLGF mRNA expression. In addition, tamoxifen reduced VEGFdriven migration of HEECs in vitro, indicating an inhibitory effect on angiogenesis. The obtained data are in line with previous reports suggesting that tamoxifen affects angiogenesis in various tissues in vivo and in vitro. 5,26,34 For example, McNamara et al reported that tamoxifen has a direct inhibitory effect on VEGF-dependent proliferation in human dermal microvessel endothelial primary cells (HMECs) grown in vitro. ${ }^{26}$

It is reasonable to believe that co-culture of cells that normally interact in a tissue, such as endometrium, will mimic the in vivo situation better than cells in monocultures. We have recently shown that HEECs grown in monoculture respond differently than HEECs grown in co-culture regarding VEGF-A, PLGF, and HIF- $1 \alpha$ mRNA expression when grown in monocultures compared with co-cultures with stromal cells. ${ }^{28}$ We therefore used a co-culture system to examine whether stromal cells could regulate tamoxifen's effects on HEECs. Indeed, the presence of stromal cells abolished the tamoxifen-induced decrease of VEGF-A mRNA expression in HEECs. Also, in the currently presented migration assay, the co-cultured HEECs seem to migrate to a higher (albeit not statistically significant) extent than monocultured HEECs, further supporting the observation that stromal cells seem to regulate some of tamoxifen's effects in HEECs. A possible effect of tamoxifen on endometrial angiogenesis might thus be mediated via either direct effects on HEECs or an indirect effect on HEECs via stromal cells.

VEGF-A is known to be a strong promoter of angiogenesis, by inducing endothelial cell proliferation, migration, sprouting, and tube formation. It is also important for the survival of endothelial cells, ${ }^{35}$ probably by inducing antiapoptotic protein expression. ${ }^{36}$ Several factors such as sex steroids and growth factors are known to be involved in the regulation of VEGF-A expression. ${ }^{37}$ We observed a decreased VEGF-A mRNA expression in monocultured HEECs exposed to tamoxifen, suggesting an antiangiogenic effect. This is in agreement with previous studies showing that tamoxifen down-regulated VEGF-A expression in human endothelial cells and breast tissue. ${ }^{26,38}$ However, the presence of stromal cells abolished the tamoxifen-induced down-regulation of VEGF-A mRNA, suggesting that the HEEC expression of VEGF-A mRNA also is under the control of the endometrial stromal cells. Tamoxifen is reported to increase VEGF production in human endometrial stromal cells, ${ }^{5}$ and it is possible that VEGF released from stromal cells regulates the VEGF-A expression in HEECs.

The expression of PLGF mRNA was upregulated after tamoxifen exposure in both mono- and co-cultured HEECs. The control of HEEC PLGF mRNA expression thus seems to differ compared with that of VEGF-A. PLGF has an antagonistic effect on VEGF-driven angiogenesis when produced by the same cells as VEGF. This is due to the formation of VEGF-PLGF heterodimers. ${ }^{39}$ In contrast, 
PLGF produced at sites other than the target cell may promote angiogenesis by increasing VEGF-A signaling through VEGFR-2. ${ }^{40}$ An upregulation of PLGF in endothelial cells may therefore have an antiangiogenic effect. However, the biological consequences for the endometrial vasculature of the increased PLGF mRNA expression in HEECs are not clear.

In the current study, it was also observed that tamoxifen caused an upregulation of VEGFR-1 mRNA in HEECs co-cultured with stromal cells but not in monocultured HEECs. VEGFR-1 acts like a decoy of VEGF-A, and may thereby regulate the amount of VEGF-A that is free to bind to VEGFR-2, which is considered to be a more central receptor in the angiogenic cascade. Tamoxifen may thus have an inhibitory effect on endometrial angiogenesis by increasing the expression of VEGFR-1.

Tamoxifen upregulated the expression of $\mathrm{ER} \beta \mathrm{mRNA}$ in HEECs with a more pronounced affect in HEECs co-cultured with stromal cells. A similar increase in ER $\beta$ expression has been shown in the endometrial vasculature when the levels of estrogen and progesterone decrease in the late secretory phase of the menstrual cycle. ${ }^{37}$ The tamoxifeninduced ER $\beta$ expression may be due to a feedback mechanism of anti-estrogenic activity of tamoxifen.

Estrogens are important in the control of normal endometrial angiogenesis, and have previously been demonstrated to induce angiogenic activities by stimulating endothelial cell proliferation and migration via binding to the classical estrogen receptors. ${ }^{9}$ The proangiogenic effects of estrogen are most likely caused by increased VEGF activity. In this study, the mRNA expression of both VEGF-A and its receptor VEGFR-1 were down-regulated in HEECs after exposure to estrogen. VEGF-A was downregulated by tamoxifen and estradiol, suggesting that tamoxifen down-regulates VEGF-A via an agonistic effect on the ER. VEGFR-1 and PLGF were upregulated by tamoxifen and down-regulated by estradiol, suggesting that tamoxifen upregulates VEGFR-1 and PLGF through an antagonistic effect on the ER. Hence, even in the same tissue and cell type, the divergent nature of tamoxifen is seen; this might be explained by ER-independent effects of tamoxifen. ${ }^{41}$

There is an array of tamoxifen metabolites with mixed agonistic and antagonistic effects on estrogen receptors, and 4-hydroxytamoxifen and endoxifen are reported to be the most pharmacologically active..$^{20,42}$ Several cytochrome P (CYP) enzymes can metabolize tamoxifen. We have previously shown a selective expression of several tamoxifen-metabolizing CYPs in glandular and surface epithelia as well as adduct formation in human endometrial biopsy samples. ${ }^{23}$ In agreement with our previous study of endometrial glands, we found no major tamoxifen-metabolizing CYPs in the endometrial vasculature, but there was distinct expression of CYP1A1 in the stroma around endometrial blood vessels and CYP1B1 in the endometrial blood vessel walls, with a high degree of interindividual variation. As a result of induction, inhibition, and polymorphism, the expression and activity of CYP enzymes normally show great interindividual variability among humans. ${ }^{43,44}$ Despite these observations, the studied individuals showed similar responses in
HEECs after tamoxifen exposure in vitro. The results suggest potential bioactivation of tamoxifen by CYP1A1/1B1 in the endometrial vasculature in vivo. However, it is most reasonable to suppose that the major effects of tamoxifen seen in this in vitro study were related to the parent compound, as the expression levels were relatively low in HEECs and stromal cells. It must be emphasized that in vivo tamoxifen undergoes significant hepatic metabolism and forms metabolites that may reach the endometrial vasculature via the systemic circulation. 4-Hydroxytamoxifen has been reported to upregulate CYP1A1 expression in MCF7 breast cancer cells in an ER-independent manner. ${ }^{41}$ In contrast, we observed down-regulation of CYP1A1 mRNA expression in tamoxifen-treated HEECs, suggesting that tamoxifen is not able to induce its own metabolism in this cell type.

In conclusion, we demonstrate that tamoxifen decreases HEEC migration and modulates the expression of angiogenesis-related genes, indicating that tamoxifen affects endometrial angiogenesis, most likely by reducing angiogenic activity. Our results also indicate that endometrial stromal cells regulate some of the effects of tamoxifen on HEECs. Also, the presence of tamoxifenmetabolizing enzymes suggests local bioactivation of tamoxifen in endometrial vasculature in vivo. The present data suggest that bleeding disturbances observed in some women during tamoxifen treatment may be associated with abnormalities in their endometrial vasculature due to tamoxifen-induced changes in the expression of angiogenesis-related genes.

\section{References}

1. Barbara KD, Leslie GF: From adjuvant therapy to breast cancer prevention: BCPT and STAR. Breast J 2001, 7:144-157

2. Jordan VC: Tamoxifen: a most unlikely pioneering medicine. Nat Rev Drug Discov 2003, 2:205-213

3. Chalas E, Costantino JP, Wickerham DL, Wolmark N, Lewis GC, Bergman C, Runowicz CD: Benign gynecologic conditions among participants in the Breast Cancer Prevention Trial. Am J Obstet Gynecol 2005, 192:1230-1237

4. Liao D, Johnson R: Hypoxia: A key regulator of angiogenesis in cancer. Cancer Metastasis Rev 2007, 26:281-290

5. Okada H, Tsutsumi A, Imai M, Nakajima T, Yasuda K, Kanzaki H: Estrogen and selective estrogen receptor modulators regulate vascular endothelial growth factor and soluble vascular endothelial growth factor receptor 1 in human endometrial stromal cells. Fertil Steril 2010, 93:2680-2686

6. Bläuer M, Heinonen PK, Rovio P, Ylikomi T: Effects of tamoxifen and raloxifene on normal human endometrial cells in an organotypic in vitro model. Eur J Pharmacol 2008, 592:13-18

7. Krikun G, Schatz F, Taylor R, Critchley HOD, Rogers PAW, Huang J, Lockwood CJ: Endometrial endothelial cell steroid receptor expression and steroid effects on gene expression. J Clin Endocrinol Metab 2005, 90:1812-1818

8. Critchley HOD, Brenner RM, Henderson TA, Williams K, Nayak NR, Slayden OD, Millar MR, Saunders PTK: Estrogen receptor $\beta$, but not estrogen receptor $\alpha$, is present in the vascular endothelium of the human and nonhuman primate endometrium $\mathrm{J}$ Clin Endocrinol Metab 2001, 86:1370-1378

9. Losordo DW, Isner JM: Estrogen and angiogenesis: a review. Arterioscler Thromb Vasc Biol 2001, 21:6-12

10. Brandenberger AW, Lebovic DI, Tee MK, Ryan IP, Tseng JF, Jaffe $\mathrm{RB}$, Taylor RN: Oestrogen receptor (ER)- $\alpha$ and ER- $\beta$ isoforms in normal endometrial and endometriosis-derived stromal cells. Mol Hum Reprod 1999, 5:651-655 
11. Lecce G, Meduri G, Ancelin M, Bergeron C, Perrot-Applanat M: Presence of estrogen receptor $\beta$ in the human endometrium through the cycle: expression in glandular. stromal, and vascular cells. Mol Hum Reprod 2001, 86:1379-1386

12. Albrecht ED, Babischkin JS, Lidor Y, Anderson LD, Udoff LC, Pepe GJ: Effect of estrogen on angiogenesis in cocultures of human endometrial cells and microvascular endothelial cells. Hum Reprod 2003, 18:2039-2047

13. Arnal J-F FC, Billon-Galés A, Favre J, Laurell H, Lenfant F, Gourdy P: Estrogen receptors and endothelium. Arterioscler Thromb Vasc Biol 2010, 30:1506-1512

14. Murdoch FE, Gorski J: The role of ligand in estrogen receptor regulation of gene expression. Mol Cell Endocrinol 1991, 78:C103-C108

15. Ball LJ, Levy N, Zhao X, Griffin C, Tagliaferri M, Cohen I, Ricke WA Speed TP, Firestone GL, Leitman DC: Cell type- and estrogen receptor subtype specific regulation of selective estrogen receptor modulator regulatory elements. Mol Cell Endocrinol 2009, 299:204-211

16. Nilsson S, Makela S, Treuter E, Tujague M, Thomsen J, Andersson G Enmark E, Pettersson K, Warner M, Gustafsson J-A: Mechanisms of estrogen action. Physiol Rev 2001, 81:1535-1565

17. Matthews J, Gustafsson J-Å: Estrogen signaling: a subtle balance between ER $\alpha$ and ER $\beta$. Mol Interv 2003, 3:281-292

18. Punyadeera $C$, Kamps R, Defrère $S$, Dijcks $F$, de Goeij $A$, Ederveen $A$, Dunselman G, Groothuis P: Effects of selective oestrogen receptor modulators on proliferation in tissue cultures of pre- and postmenopausal human endometrium. J Steroid Biochem Mol Biol 2008, 112:102-109

19. Mourits MJE, Hoor KAT, van der Zee AGJ, Willemse PHB, de Vries EGE, Hollema $\mathrm{H}$ : The effects of tamoxifen on proliferation and steroid receptor expression in postmenopausal endometrium. J Clin Patho 2002, 55:514-519

20. Desta Z, Ward BA, Soukhova NV, Flockhart DA: Comprehensive evaluation of tamoxifen sequential biotransformation by the human cytochrome P450 system in vitro: prominent roles for CYP3A and CYP2D6. J Pharmacol Exp Ther 2004, 310:1062-1075

21. Boocock DJ, Brown K, Gibbs AH, Sanchez E, Turteltaub KW, White $\mathrm{INH}$ : Identification of human CYP forms involved in the activation of tamoxifen and irreversible binding to DNA. Carcinogenesis 2002, 23:1897-1902

22. Crewe HK, Notley LM, Wunsch RM, Lennard MS, Gillam EMJ: Metabolism of tamoxifen by recombinant human cytochrome P450 enzymes: formation of the 4-hydroxy, 4'-hydroxy and N-desmethyl metabolites and isomerization of trans-4-hydroxytamoxifen. Drug Metab Dispos 2002, 30:869-874

23. Andersson H, Helmestam M, Zebrowska A, Olovsson M, Brittebo E: Tamoxifen-induced adduct formation and cell stress in human endometrial glands. Drug Metab Dispos 2010, 38:200-207

24. Shang $Y$, Brown M: Molecular determinants for the tissue specificity of SERMs. Science 2002, 295:2465-2468

25. Hague S, Manek S, Oehler MK, MacKenzie IZ, Bicknell R, Rees MCP: Tamoxifen induction of angiogenic factor expression in endometrium $\mathrm{Br} \mathrm{J}$ Cancer 2002, 86:761-767

26. McNamara DA, Harmey J, Wang JH, Kay E, Walsh TN, BouchierHayes DJ: Tamoxifen inhibits endothelial cell proliferation and attenuates VEGF-mediated angiogenesis and migration in vivo. Eur J Surg Oncol 2001, 27:714-718
27. Haran EF, Maretzek AF, Goldberg I, Horowitz A, Degani H: Tamoxifen enhances cell death in implanted MCF7 breast cancer by inhibiting endothelium growth. Cancer Res 1994, 54:5511-5514

28. Helmestam M, Stavreus-Evers A, Olovsson M: Cadmium chloride alters mRNA levels of angiogenesis related genes in primary human endometrial endothelial cells grown in vitro. Reprod Toxicol 2010, 30:370-376

29. Moberg C, Catalano RD, Charnock-Jones DS, Olovsson M: VEGF-A and Serum withdrawal induced changes in the transcript profile in human endometrial endothelial cells. Reprod Sci 2010, 17:590-611

30. Bredhult C, Bäcklin B-M, Olovsson M: Effects of some endocrine disruptors on the proliferation and viability of human endometrial endothelial cells in vitro. Reprod Toxicol 2007, 23:550-559

31. Bredhult C, Sahlin L, Olovsson M: Gene expression analysis of human endometrial endothelial cells exposed to op'-DDT. Mol Hum Reprod 2008, 14:97-106

32. Bredhult C, Sahlin L, Olovsson M: Gene expression analysis of human endometrial endothelial cells exposed to Bisphenol A. Reprod Toxicol 2009, 28:18-25

33. Muller PY JH, Miserez AR, Dobbie Z.: Processing of gene expression data generated by quantitative real-time RT-PCR. Biotechniques 2002, 32:1372-1374, 1376, 1378-1379

34. Garvin S, Nilsson UW, Dabrosin C: Effects of oestradiol and tamoxifen on VEGF, soluble VEGFR-1, and VEGFR-2 in breast cancer and endothelial cells. Br J Cancer 2005, 93:1005-1010

35. Lee S, Chen TT, Barber CL, Jordan MC, Murdock J, Desai S, Ferrara $\mathrm{N}$, Nagy A, Roos KP, Iruela-Arispe ML: Autocrine VEGF signaling is required for vascular homeostasis. Cell 2007, 130:691-703

36. Otrock ZK, Makarem JA, Shamseddine AI: Vascular endothelial growth factor family of ligands and receptors: review. Blood Cells Mol Dis 2007, 38:258-268

37. Speroff Leon, Marc F: Clinical Gynecologic Endocrinology and Infertility. Philadelphia, Lippincott Williams \&Wilkins, 2005

38. Garvin S, Dabrosin C: Tamoxifen inhibits secretion of vascular endothelial growth factor in breast cancer in vivo. Cancer Res 2003, 63:8742-8748

39. Schomber T, Kopfstein L, Djonov V, Albrecht I, Baeriswyl V, Strittmatter K, Christofori G: Placental growth factor-1 attenuates vascular endothelial growth factor-A dependent tumor angiogenesis during $\beta$ cell carcinogenesis. Cancer Res 2007, 67:10840-10848

40. Cao Y: Positive and negative modulation of angiogenesis by VEGFR1 Ligands. Sci Signal 2009, 2:re1.

41. DuSell CD, Nelson ER, Wittmann BM, Fretz JA, Kazmin D, Thomas RS, Pike JW, McDonnell DP: Regulation of aryl hydrocarbon receptor function by selective estrogen receptor modulators. Mol Endocrino 2010, 24:33-46, 24:33-46

42. Kim SY, Laxmi YRS, Suzuki N, Ogura K, Watabe T, Duffel MW, Shibutani S: Formation of tamoxifen-DNA adducts via O-sulfonation, not O-acetylation, of alpha-hydroxytamoxifen in rat and human livers. Drug Metab Dispos 2005, 33:1673-1678

43. Ingelman-Sundberg M, Sim SC, Gomez A, Rodriguez-Antona C: Influence of cytochrome P450 polymorphisms on drug therapies: pharmacogenetic, pharmacoepigenetic and clinical aspects. Pharmacol Ther 2007, 116:496-526

44. Lin JH, Lu AYH: Inhibition and induction of cytochrome P450 and the clinical implications. Clin Pharmacokinet 1998, 35:361-390 